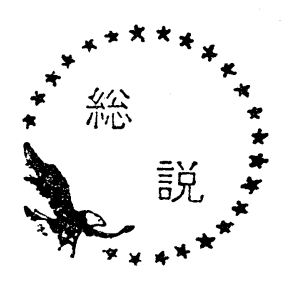

1. 緒

石炭をガス化，液化などの転換プロセスをへてクリ ーンエネルギー源とするための技術開発はアメリカを 始め世界的に重点的な研究課題として行なわれてい る。一方石炭は治金用コークス源として重要である が，良質な粘結炭の不足をきたしているので劣質な石 炭での代替することが研究課題である。

これらの石炭利用反応を理解するには, 石炭の構 造, 当該反応機構について深い知識を必要とすること は今更いらまでもない。石炭の化学構造はよく知られ ているよらに多環芳香族を骨核とし，これに側鎖脂肪 族， $\mathrm{OH}, \mathrm{COOH}, \mathrm{CO}$ などの官能基が結合している ものとされている1)。このような構造単位体（一次構 造）がさらにー- $\mathrm{CH}_{2}$-，一Oーなどを介して，また直接 結合して巨大な架橋型高分子重合体を形成していると 考えられている2)。

しかし構造単位体の結合様式, 架橋密度, ならびに 構造単位体間，分子間の凝集状態（ここではこれらを 一括して高次構造と呼ぶことにする）についてはあま り多くの研究はない。高次構造が石炭の物性, 性状と 密接に関連することは容易に想像されるところであ る。石炭に溶剤を作用させると，石炭中に共存する低 分子成分が抽出されると同時に，石炭高分子本体は溶 解の前駆現象である膨潤作用を示す。膨潤機構を検討 することにより，石炭構造単位体同志の結合様式，凝 集力について知見がえられるであろら ${ }^{233}$ 。このよう な石炭への低分子溶媒の作用は, 石炭の溶剂抽出によ る石炭の精製（例党ば Solvent Refined Coal Process), 石炭のコークス化, 粘結性機構の解明につなが るものである。石炭をタール系(時には石油系)溶剤に 䀣濁せしめ, 水素化分解, 加溶媒分解するプロセスに ついても石炭と溶媒との相互作用に注目する必要があ る。石炭 (高分子) 同志の相互作用 (相溶作用 $)^{4) ~ 6)}$, コークス製造時の配合の問題にもつながるであらう。

*本論文は日本化学会第35秋季年会特別講演特 $2 \mathrm{Q}$ 18 (昭51.8.28) が骨子となっている。 **工学部 札幌市北区北13条西 8 丁目
このような石炭の高次構造と, 広い意味での相溶性 は単に学問的な與味だけでなく, 工業的にも重要な課 題である。本稿ではこのような観点から二, 三の知見 を紹介することとした。

\section{2. 石炭構造単位体の結合様式}

ピリジン溶媒による石炭高分子重合体の膨潤量から (1)式で示される Flory-Rehner 式を用いて架橋間分 子 $M_{c}$ を求めることが出来る。

$$
M_{c}=\rho_{2} V v_{2}{ }^{1 / 3} /\left\{-\ln \left(1-v_{2}\right)-v_{2}-\chi v_{2}{ }^{2}\right\}
$$

ここで $\rho_{2}$ は溶液中での石炭の密度， $V$ はピリジンの 分子容， $v_{2}$ は平衡膨潤時に打ける石炭の容積分率で

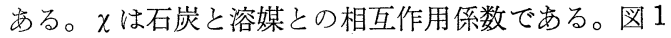
に $M_{c}$ の石炭化度による推移を示した**。

れはピリジン可溶分の浸透圧の濃度依存性から求め られる第 2 ビリアル係数より算定したものであり，(1)

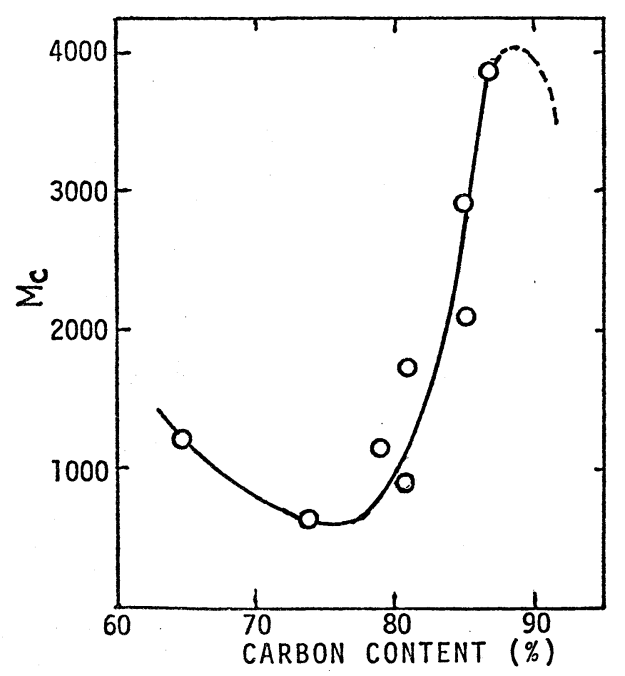

図 1 架橋間分子量の石炭化度による変化

**本データーは既報 (Sanada Y. Honda : Fuel, 45, 295 (1966) の $M_{c}$ 值を改訂したものである。パラ メータ一, 定数, 計算のクロスチェックについて Dr. J. R. Nelson, The Pennsylvania State University, Pa., USA の助言をえたことを記し，謝 意を表する。 
式への代入にはな和検討すべき点を残している。 值いかんでは $M_{c}$ 大きく変わる。しかし前記の点が 妥当とずれば C80\% 付近の石炭の $M_{c}$ がもっとも 小さく，それよりる高石炭化度炭添ど $M_{c}$ は大きく なっている。90\% 以上の石炭では $M_{c}$ は再び減少す るものと思われる。架橋密度 $\left(1 / M_{c}\right)$ は硬度, 粉砕 性などの機械的性質，ガラス転移現象などとも密接に 関連する7。

3. 石炭の溶剂抽出と溶解度パラメーター

石炭のピリジン抽出量と石炭化度との関係は図 $2^{18)}$ にみられるように，C85\% 付近飞極大值がみられる。 また抽出されるるのの分子量も多量化抽出されるもの ほど大きいことがわかる(図 3$)^{18)}$ 。ピリジンのかわり にクロロホルムを溶㓮に用いても図 $2 ， 3$ と同じ傾向 と㐫る。

モノエタノールアミン，エチレンジアミンなどの含 窒素極性溶剤を用いると低石炭化度炭ほど抽出量が多 い。このように溶剤の種類により抽出量が異なり，そ の現象はさわめて複雑である。図4

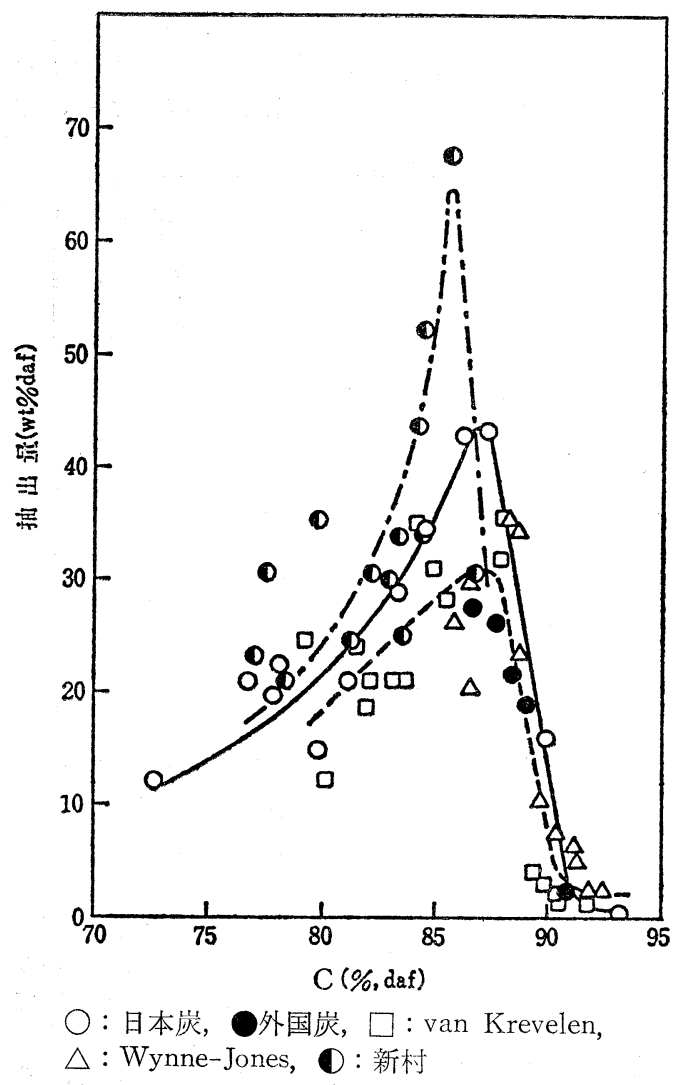

図 2 石炭化度とピリジン抽出量との関係

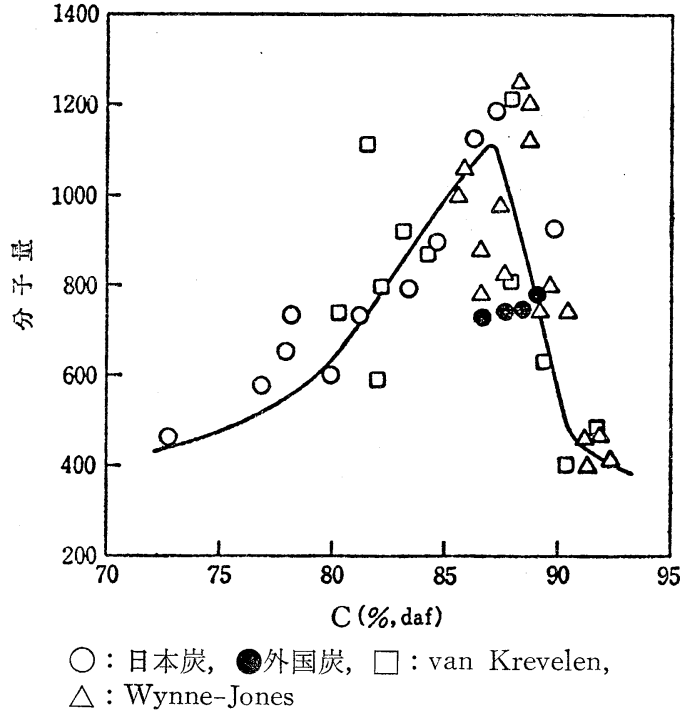

図 3 石炭化度とピリジン抽出物の分子量との関係

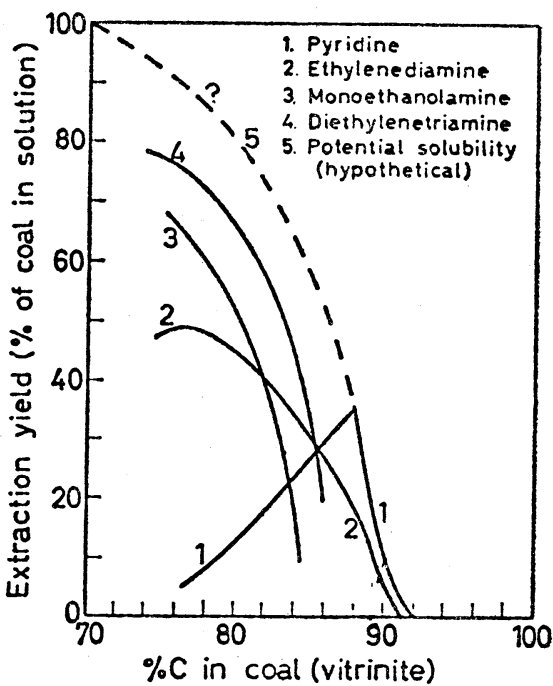

図 4 各種溶媒を用いたさいの抽出量と石炭化度 との関係

によりまとめられた石炭の溶剤抽出量と石炭化度との 関係を示した ${ }^{17)}$ 。ピリジン，キノリン型の溶媒とエタ ノールアミン型溶媒の両方を兼ね備觉た理想的な溶媒 があれば，低石炭化度炭ではほとんど溶媒に溶けるこ とになる。

Hildebrand, Scott の非電解質の溶解度理論によ ると, 溶質と溶剤の分子間凝集力が近いものほど溶解 度が大きいことが示される。

$$
\chi=\beta+\left(V_{1} / R T\right)\left(\delta_{1}-\delta_{2}\right)^{2}
$$




$$
\beta=(1 / z)(1-1 / m)
$$

$\chi$ は溶質と溶媒の相互作用係数で，(2)式の第 2 項はエ ンタルピー部分の寄与である。(3)式の第 1 項のなかで $z$ は格子配位数, $m$ は格子中に占める溶媒分子の場 所の数である。

$\delta_{i}$ は溶解度パラメーターで $\delta_{i}=\sqrt{\frac{\Delta E_{i}^{V}}{V_{i}}}$ で示され る分子間力（内部圧力）である。添字 2,1 はそれぞ れ溶質, 溶剤を示す。石炭の溶剤抽出量を溶解度パラ メーターを尺度として整理すると何れの場合も $\delta_{1}$ が 10〜12程度の溶媒を用いたときに抽出量が極大とな る。van Krevelen によると石炭の溶解度パラメータ 一は(4)式で与えられる ${ }^{17)}$ 。

$$
\delta=\frac{\sum_{i}\left(N_{i} / C\right) F_{i}}{\boldsymbol{M}_{C} / d}=\frac{\sum_{C}}{\boldsymbol{M}_{C} / d}
$$

$$
\Sigma_{C}=68.5 \mathrm{H} / \mathrm{C}+3000 / \mathrm{C}+115 \mathrm{~N} / \mathrm{C}+225 \mathrm{~S} / \mathrm{C}
$$$$
+66.5 f_{a}
$$

$\mathbf{M}_{C}=12.00+1,008 \mathbf{H} / \mathbf{C}+16.000 / \mathbf{C}+\cdots$

H/C， O/C，N/C，S/C，はそれぞれ原子比で表し た数字で, $f_{a}$ は芳香族性分率を示す。 $\mathbf{M}_{C}$ は既約分子 量, $d$ は密度, $\sum_{i}\left(N_{i} / C\right) F_{i}$ 之 $\mathrm{H} / \mathrm{C}, \mathbf{O} / \mathbf{C}, \mathbf{N} / \mathbf{C}$, $\mathbf{S} / \mathbf{C}$ ならびに $f_{a}$ を用い，上式より $\delta$ が計算され
る。大沢らは日本炭, 外国炭16種について $\delta$ を分析值 から計算している。その結果を van Krevelen の值 とともに図 5 に示す ${ }^{18)}$ 。石炭の溶解度パラメーターは C $90 \%$ 付近に極小点があるように見受けられる。

一方 Kirov らも同じような観点から石炭の膨潤度 （容量比）を求めているが，いずれも $\delta_{1}=11$ の溶剤 がもっとも石炭をよく膨潤させる ${ }^{19) 。 ~}$

このように石炭と溶剤との相互作用は $\delta$ によりかな りよく理解されるが, 図 1 からもわかるよらに石炭本 体の 3 次元架橋構造や，石炭中の官能基の形成する水 素結合と極性溶剂を用いるさいの両者の発熱による前 記理論の適用の限界などが指摘されよう。

高分子量の溶質が溶媒に溶けるためには, 両者の混 合にさいしての自由エネルギー変化 $(\Delta G)$ が負であ る必要がある。 $\Delta G$ が負になるためには $\chi$ が小さい ことが絶体必要である。 $\chi_{S}(\chi$ エントロピー 部分) は 両者の交換エントロピーであり, 高分子重合体につい ての実験から $\chi_{S}=0.35(0.3 \sim 0.4)$ でほぼ一定值を 与えることが知られている ${ }^{8) 99}$ 。混合のためのエネル ギーに関与するパラメーター $\chi_{H}$ は

$$
\chi_{H}=\left(V_{1} / R T\right) A_{12}
$$

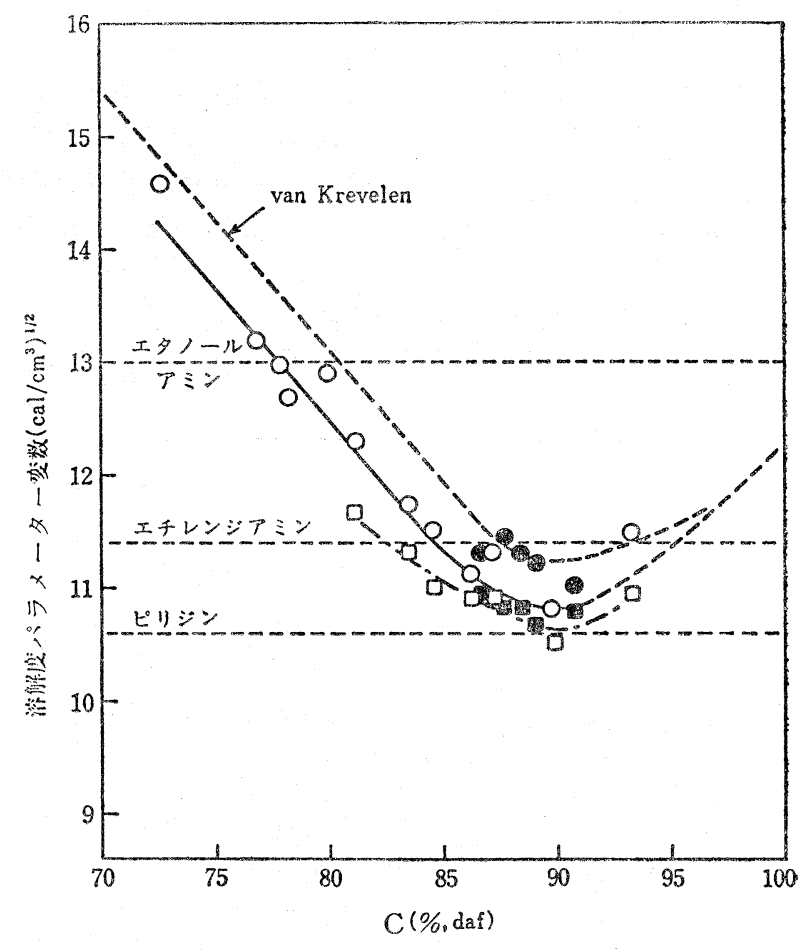

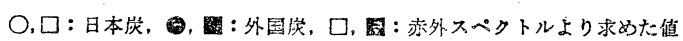

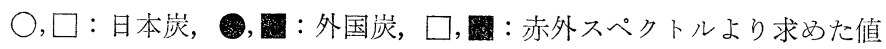
図 5 石炭化度と溶解度変数との関係 
で与兄らるが， $\chi_{H}$ は0.15以下 $\left(\chi=\chi_{S}+\chi_{H}\right.$ として 0.5 以下）でないと溶解しない。 $A_{12}$ はいわゆる交換 エネルギー密度である。通常の溶媒では $R T / V_{1} \simeq 6$ $\mathrm{cal} / \mathrm{cm}^{3}$ であるから $A_{12} \leq 1.0$ となら权ばならない。 $A_{12}$ は(2)式と全く同様

$$
A_{12}=\left(\delta_{1}-\delta_{2}\right)^{2}
$$

で与えられる。しかし極性溶媒を使用した場合のよう 飞両者間で特別の凝集効果が働く場合は

$$
A_{12}=\left(\delta_{1}-\delta_{2}\right)^{2}+2(1-K) \delta_{1} \delta_{2}
$$

で示されるように補正項（(9)式に和ける第2 項, 換言 すれば補正係数 $K$ ) を挿入する必要がある ${ }^{10)} 。 K=1$ のときは(8)式と同じで正常な場合を意味し， $K>1$ の ときは両者に特別の作用，たと党ば水素結合の生成な ぞが生じた場合である。 $K>1$ のとき $A_{12}$ は負の值 になる方向であり，発熱を伴なって混合（溶解）する ようになる。 $K<1$ のときは混合, 溶解は起らない。 この $K$ 值はまったく実験的, 経験值であって理論的 根拠はない。

一方理論的な見地からは

$$
A_{12}=\left(\lambda_{1}-\lambda_{2}\right)^{2}+\left(\tau_{1}-\tau_{2}\right)^{2}
$$

または

$$
A_{12}=\left(p_{1}{ }^{+}-p_{2}{ }^{+}\right)\left(p_{1}^{-}-p_{2}^{-}\right)
$$

が知られている。 $\lambda, \tau$ は $\delta$ のち無極性, 有極性の

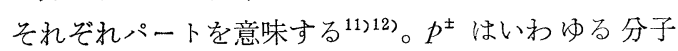
の極性 (polarity) であり $p^{ \pm}=S \varepsilon /(2 r)^{1 / 2}$ で与えら れる ${ }^{13)} 。 S$ は分子の接触時の表面原子の割合, $\varepsilon$ は 点接触の荷電量, $r$ 以荷電体と接触点との距離であ
る。

いずれにしても石炭の溶剤抽出, 相溶性を考光るに 西たって, 分子間凝集力に関連する溶解度パラメータ 一なる概念で当該現象（反応）を理解するのが有力な アプローチの一つであることは間違いない。さらに上 述のごとく，溶媒の極性をあらわす polarity のほか に reducebility $\delta_{b}$, proton donner capacity $\delta_{a}$ を加 味して議論の深化がなされるであるら ${ }^{14}$ 。

J.M. Angelovich らは石炭の溶解性飞関する研究 を, 前述の溶解度理論の上に立って行なっている ${ }^{15)}$ 。 彼らの用いた溶媒は表 1 に示すように純溶媒から混合 溶媒にまでわたっている。溶媒の選定にあたっては石 炭の溶剂抽出（加圧下，水素雾囲気下）にさいして熱 的安定なこと, 水素供与能のあることを念頭に抽いて いるが, 実験には水素供与能の相異を減殺するため石 炭に $0.5 \%$ の $\mathrm{Fe}^{3+}$ を含浸せしめている。2,000 psi, $825^{\circ} \mathrm{F}, 3$ 時間と反応条件を一定にして水素雾囲気下 で反応したときの原炭のベンゼン不溶分の可溶化率 （転化率）を無極性溶解度パラメーターで整理したの が図 6 である。溶媒の極性, 水素結合能が同じであれ ば，両者の溶解度パラメーターが等しいときに転化率 がもっとも大きいことになる。同図からは $\delta_{2} \doteqdot 9.5$ となる。

石炭の溶剤抽出に西たって Kiebler の研究 ${ }^{16)}$ がよ く知られているが, Angelovich らは溶媒の極性, 水

\begin{tabular}{|c|c|c|c|}
\hline Solvent & $\begin{array}{l}\text { Boiling Point at } \\
760 \mathrm{Mm} . \mathrm{Hg},{ }^{\circ} \mathrm{F} .\end{array}$ & $\begin{array}{l}\text { Density at } 77^{\circ} \\
F ., \quad G / c c\end{array}$ & $\begin{array}{c}\text { Nonpolar Solubility Parameter at } \\
77^{\circ} \mathrm{F} .,(\text { cal. } / \mathrm{cc} .)^{1 / 2}\end{array}$ \\
\hline Hexane & 156 & 0.654 & 7.3 \\
\hline Benzene & 176 & 0.876 & 9.2 \\
\hline Cyclohexane & 177 & 0.775 & 8.2 \\
\hline Phenol & 358 & 1.070 & 9.9 \\
\hline Tetralin & 406 & 0.966 & 9.4 \\
\hline Coal tar fraction $\mathrm{A}$ & 464 & 1.028 & 9.7 \\
\hline Coal tar fraction $\mathrm{B}$ & 524 & 1.056 & 9.8 \\
\hline Hydrogenated coal oil A & 604 & 1. 030 & 9.3 \\
\hline Coal tar fraction $\mathrm{C}$ & 697 & 1.130 & 10.2 \\
\hline Hydrogenated coal oil B & 731 & 1.133 & 10.4 \\
\hline Hydrogenated road tar & 747 & 1.209 & 10.3 \\
\hline Coal tar fraction $\mathrm{D}$ & 795 & 1. 100 & 10.0 \\
\hline Coal tar fraction $\mathrm{E}$ & 820 & 1.150 & 10.4 \\
\hline Road tar & 945 & 1.225 & 10.5 \\
\hline
\end{tabular}
素結合能についての役割を評価する目的で追試を行な っている (図7 参照)。図に示されているように溶媒

\section{表 1 溶媒 の物理的諸性質}




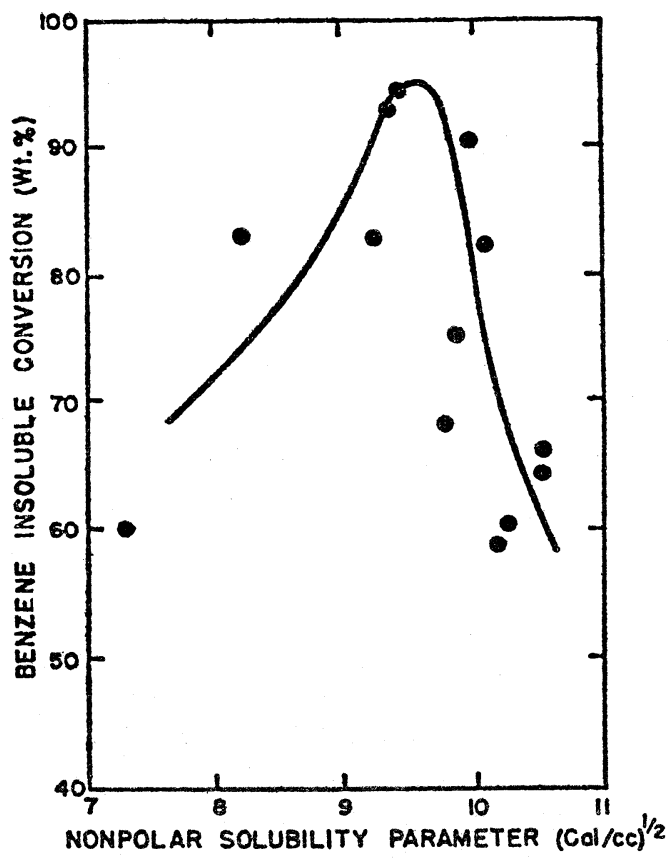

(試料石炭 C(d.a.f) $74.6 \%$ )

図 6 溶媒の Solubility Parameter（無極性部 分）とベンゼン可溶化率との関係

の Class I は強力な水素結合により 3 次元網目を形 成するグループ，Class II は溶媒分子中に 活性水素 と, 供与能をるつ原子をともに有するグループであ る。ここで活性水素は酸素など electronegative atom についた水素, 供与性原子とは水素の結合していない electronegative atom をいら。Class III は供与能の ある原子を含をが活性水素は含まないもの, Class IV は Class III と反対のグループ, Class V はその他
のグループである。このようにグループ別にするとい ずれも $\delta_{1} \doteqdot 9.5$ 付近で抽出量が極大を示す。このよ らに溶媒を類別に整理すれば溶剤抽出量は $\delta$ でよく整 理されるが，彼等はこのほか Lewis 塩基度の概念も 臫入すべさであると指摘している。

これらの実験は実用的な見地（例えば SRC の製 造）からは興味深いが, 理論の厳密性の点からは, 著 者ら ${ }^{22)}$ が以前に行なったよらに $25^{\circ} \mathrm{C}$ での平衡膨潤度

(熱力学的平衡量）の測定からの議論を進めた方がよ いように思われる。

溶剂抽出の機構, 速度論的取扱いについては最近, 神谷 ${ }^{20)}$ 大内 ${ }^{21)}$ の研究や総説 ${ }^{11}$ があるので本稿では 割愛する。

4. 石炭の加熱による抽出量の変化

粘結炭を加熱するとクロロホルム，ピリジンなどに 可溶な成分が次第に増加し, $400^{\circ} \mathrm{C}$ 付近に極大抽出量 があることが知られている。一方非粘結炭では加熱に 伴って抽出量は減少の一途をたどる。（この現象，機 構を論ずるのは本稿の目的でないので割愛する。）し かしここで増大した可溶, 可融成分は石炭の相溶性に 及ぼす大きな因子である。すなわち石炭のような高分 子物同志が，常温で分子または分子集団（ミセル）の 次元で均一に混合することは考えにくいし，熱力学的 な考察からも裏つけられているところである。

しかし温度をあげれば図 8 に示すよらに $\chi$ は低下す るであろら。相溶性をあげるためには溶融する比較的 低分子量物質の量, 分子量とその分布が重要な因子で あろら。2から4までに述べた知見を総合すれば，加 熱下に和いては夕張炭のような粘着炭同志の相溶性が もっとも大きいことになる。すなわち石炭中に元来か ら亦る被抽出物の量が多く，かつその分子量も大き

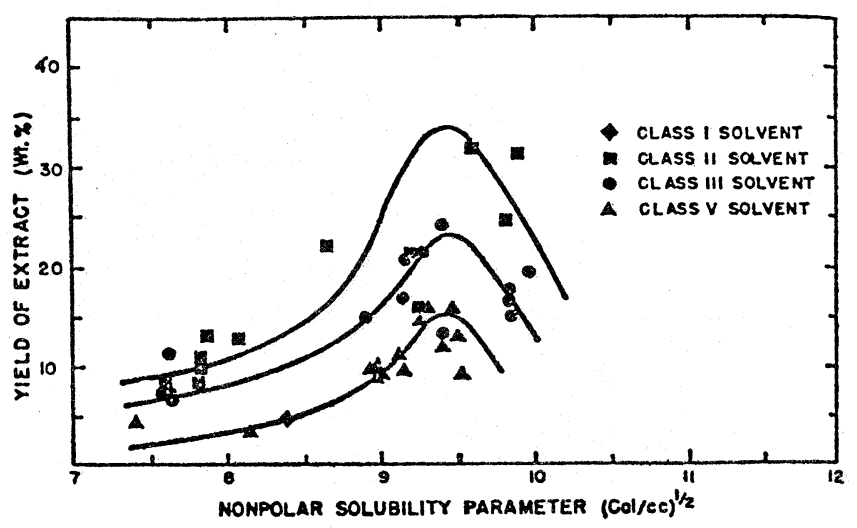

(試料石炭 C(d.a.f.) 85.4\%)

図 7 溶媒の Solubility Parameter（無極性部分）と抽出量との関係 


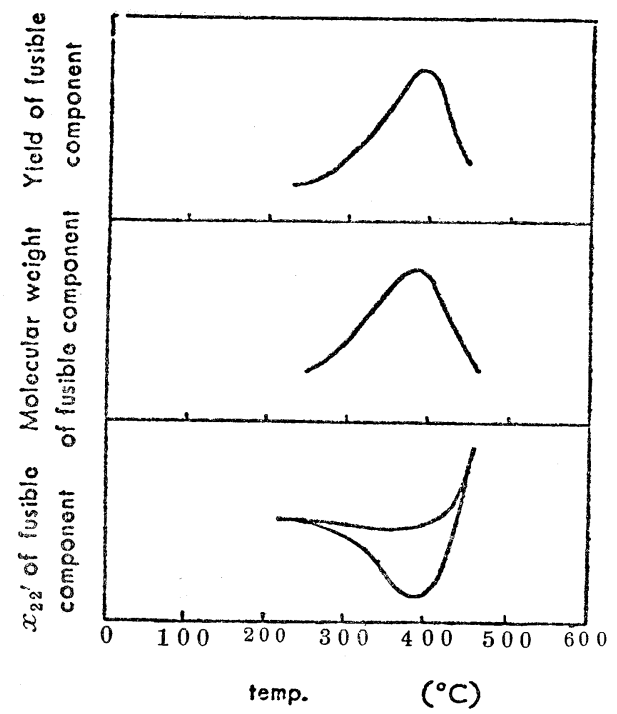

図 8 加熱下における石炭一石岸系の相溶性を具 現すべさ条件（模式図）

く，（加熱時に新たに生成するものも含めて），かつ本 体高分子自身の分子量が小さく, 架橋密度の小さいこ とが相溶性を高めることに寄与することになろう。コ 一クス製造に当たって相溶性を高めることはコークス 品位の向上には必要条件であるけれぞも十分条件でな いことを指摘したい。同時に熱力学的な考察とともに 速度論的な考察も併せて行なら必要があるう。

石炭 (有機物) の $350 \sim 550^{\circ} \mathrm{C}$ の温度範囲の挙動は コークス化, 液化プロセスにとって重要な温度範囲で あるが, この間で熱分解, 解重合, 重縮合の諸反応が 競合する。それぞれの反応の兼合による低分子成分の 量と質, 共存する高分子成分の量と質, 母相への分散 状態によりこの間の石炭の挙動, 特徴を理解する必要

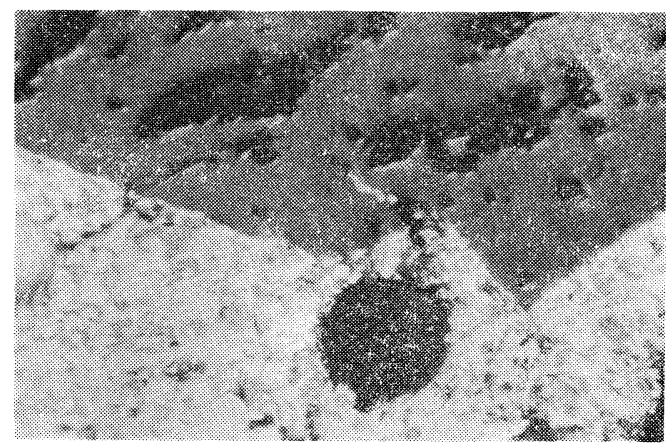

非粘結炭（相溶性なし）
があろら。

図9 は重質油を石炭に添加し，950 C で炭化して えられるコークスの偏光顕微鏡写真を示す。非粘結炭 の場合には粒子の形状がはっきり見光, 两者間に相溶 性のないことがわかる。非粘結炭の相溶性を高めるに は例えば SRC のような形でそれ自身の改質をする必 要があらう。

5. Carbonaceous mesophase ならびにその前駆 体と母相マトリックスとの相溶性

石炭はきわめて複雑な構造を有して和り, その本性 を十分に理解されるに到っていないが，アスファル ト，ピッチ類を炭化初期段階の温度で加熱してえられ る光学的暴方性の液晶の一種メソフェース (Carbonaceous mesophase) は石炭のモデルと考劣ることが できる。すなわちメソフェースは多䍗芳香族の扁平な 分子が招互いに平行に積層した檴造を有し，ピリジ ン，キノリンに不溶な物質(QI 成分または $\alpha$ 成分)で ある。キノリン可溶, ベンゼン不溶な $\beta$ 成分 (BI・ QS）は化学組成的には QI とほとんぞ同一であり， メソフェースの前駆体とみることができる。

BI・QS 成分は単独では溶融しないが，BS 成分が わずかでも共存すると溶融性となり，高温度に熱処理 することにより光学的異方性のコークスとなる。この 場合ニードルコークスとなるか, モザイックコークス となるかはピッチ成分の相性（広い意味での相溶性） によると考えられる。QI は BS と混合加熱しても溶 融せず，生成コークスの配向性は悪い。

QI 成分もある種のタール系溶剤に可溶（機械的攪 拌は可溶化が促進される）でせるが，この種溶剤の探 索あるいは積極的にQI 成分を改質して可溶可融化す ることが考えられる。持田, 竹下らはこのような観点 から Birch 還元 (水素化), 還元的アルキル化, 不均

図 9 石炭一重質油共炭化物（コークス）の偏光顕微鏡写真 $(\times 250)$ 
表 2 ピッチの抽出成分の組合せによる炭化収率

(配合率は50:50)

\begin{tabular}{cccc}
\hline $\begin{array}{c}\text { 配合率 } \\
(50: 50)\end{array}$ & $\begin{array}{c}\text { 炭化収率蛽値 } \\
\left(C_{e}\right)\end{array}$ & $\begin{array}{c}(\%) \\
\text { 計算值 } \\
\left(C_{c}\right)\end{array}$ & $\frac{C_{e}-C_{c}}{C_{c}} \times 100$ \\
\hline$\alpha+\gamma_{1}$ & 57.93 & 44.99 & 20.80 \\
$\alpha+\gamma_{2}$ & 73.81 & 68.28 & 8.19 \\
$\alpha+\gamma_{4}$ & 81.32 & 80.23 & 1.36 \\
$\beta+\gamma_{1}$ & 48.23 & 43.76 & 10.44 \\
$\beta+\gamma_{2}$ & 32.24 & 25.36 & 27.13 \\
$\gamma_{1}+\gamma_{2}$ & 42.68 & 36.26 & 17.71 \\
$\gamma_{1}+\gamma_{4}$ & 46.63 & 42.37 & 10.05 \\
$\gamma_{2}+\gamma_{3}$ & 60.23 & 51.49 & 16.10 \\
$\gamma_{2}+\gamma_{4}$ & 64.90 & 57.60 & 12.67 \\
$\gamma_{3}+\gamma_{4}$ & 68.49 & 68.49 & - \\
\hline
\end{tabular}

（註）単独成分の炭化率 $\alpha: 85.9 \%$

$\beta: 77.4 \%$

$\gamma_{4}: 74.6 \%$

$\gamma_{3}: 62.4 \%$

$\gamma_{2}: 40.6 \%$

$\gamma_{1}: 10.1 \%$

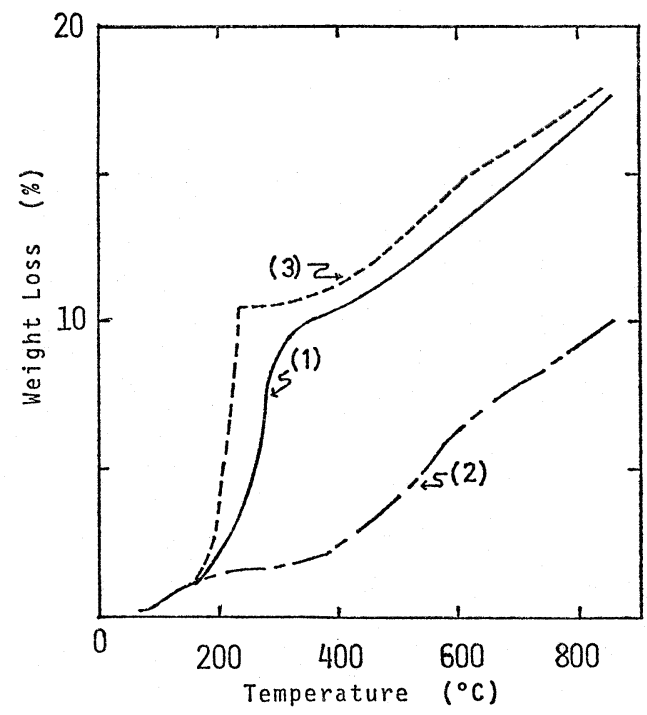

曲線(2)は BI 成分のみの場合を示す

図 10 コールタールピッチ BI 成分にピレンを 添加したさいの TG 曲線

一触媒による高圧下水素化，フリーデルクラフト反応 を試みている(4) 6)。このような QI 成分の改質はとり もな和さず石炭の解重合, 液化のモデルとして位置づ けられよう。

QI 成分の改質反応時にも共存する BS 成分(溶剂)
が大きな効果を有していることも，石炭の当該反応を 理解するのに重要な点である。

共存成分の相互効果の単純な例として，コールター ルピッチ抽出成分の組合わせによる炭化収率を表 2 飞 示した ${ }^{23)}$ 。 $\alpha$ 成分， $\beta$ 成分に $\gamma$ 成分 (Wheeler 法に よる分別)， $\gamma$ 成分同志の混合に上るだけで，計算上 の炭化収率と実測值が大きく異なることがわかる。

さらに単純なケースとして図10の 例を示す。コ一 ルタールピッチの BI 成分にピレンを外割で $4.95 \times$ $10^{-4} \mathrm{~mol} / \mathrm{g}$ 添加して TG 曲線を測定すると(1)となる。 同じ条件でピレン単味のブランク実験と, ピレン添加 率を加重して合成曲線を計算したのが(3)である。ピレ ンの昇華温度沸点以上でもピレンが $\mathrm{BI}$ と共存してい ることが，(1)と(3)を比較することから明らかである。 両者の強い相互作用が示唆される ${ }^{24)}$ 。

さらにピレンの添加による BI の可溶化についてギ 一七ラー流動曲線を求めてみた結果を図11，12 亿示 す。ピレンを外割 $5 \%$ 添加すると BI は明らかに可 溶性となり, 添加率の増大とともに最高流動度は上昇 する。固化温度は添加率にあまり影響されないが，軟 化開始温度, 最高流動温度はともに低下する。最高流 動温度はピレンの沸点以上であることは興味深い24)。

メソフェースの偏光顕微鏡観察（消光じまと多色性 の角度依存性）から，メソフェースを構成する炭素層 面（多環芳香族核）の積層面の方位を決定することが できる。このような炭素層面の 積層構造（組織構造 Texture）も高次構造のカテゴリーに入れることがで きよう。組織構造は, 出発物質の化学構造, 熱分解,

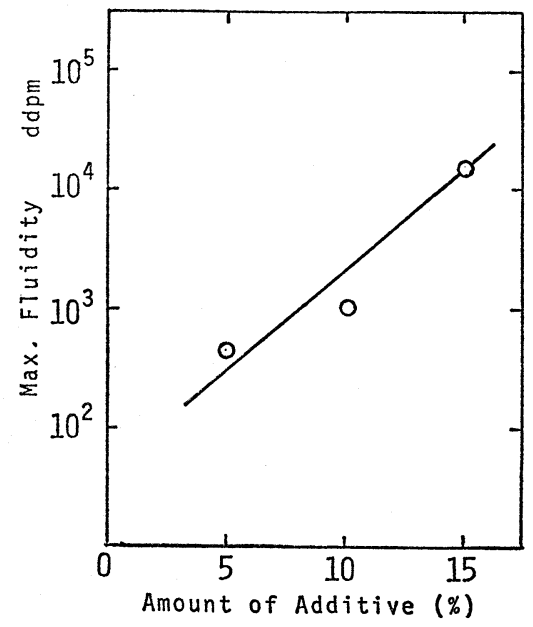

図 11 コールタールピッチ BI 成分にピレンを 添加したさいのギーセラー流動性と添加 率との関係 


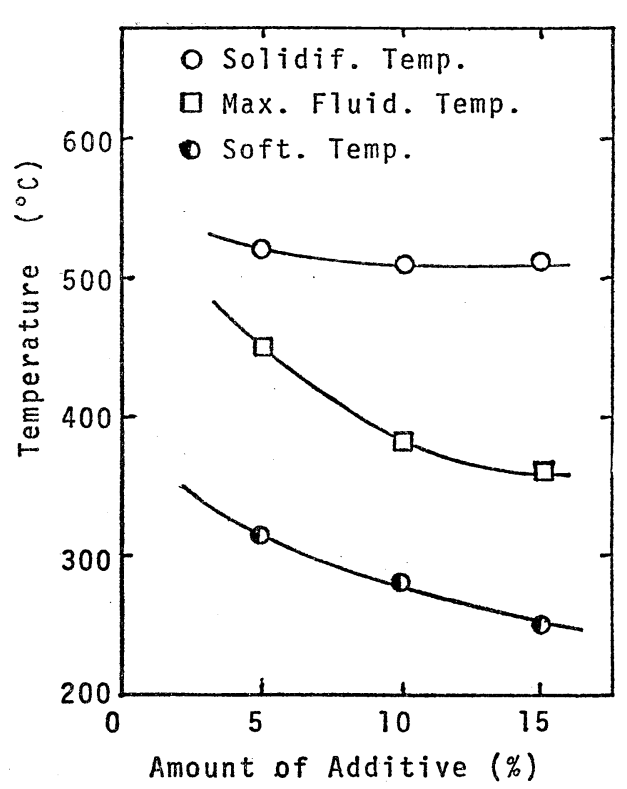

図 12 コールタールピッチ $\mathrm{BI}$ 成分にピレンを 添加したさいのギーセラー 流動特性温度 と添加量との関係

重縮合過程の履歴に関連する。このようなメソフェー ス生成機構は，均一液相からの晶折現象であることに ほかならないので，本反応の本質を究明をすれば，そ の逆反応がとりもな和さず石炭の解重合, 液化反応に つながるともいえよう。

\section{6. 綰 言}

以上石炭の高次構造と相溶性について, メソフェー スに関係する最近の知見も加兄て概観した。しかし既 述のごとく当該分野は工業的にもきわめて重要にもか かわらず，まだ未知のことがあまりにも多い。今後の 研究の加速を期待するものである。

\section{文献}

1）大内公耳, 燃協誌, 56, 779 (1977)

2）真田雄三，燃協誌，42, 34 (1963)

3）真田雄三，資技試報告，No.60，(1965）
4) I. Mochida, K. Amamoto, K. Maeda, K. Takeshita, Fuel 56, 49 (1977)

5）持田，天本，前田，竹下，然協誌，56，187(1977)

6) 持田, 天本, 前田, 竹下, 石油誌, 20, 1025 (1977)

7）真田雄三，燃協誌，42，238（1963）

8) P. J. Flory, J.Chem. Phys., 10, 51 (1942)

9) M. L. Huggins, J. Amer. Chem. Soc., 64, 1712 (1942), Ind. Eng. Chem. (Industr.) 35, 216 (1943)

10) E. E. Walker, J. Appl. Chem., 2, 470 (1952)

11) P. A. Small, ibid., 3, 71 (1953)

12) R. F. Blanks, J. M. Prausnitz, Ind. Eng. Chem. (Fund.) 3, 1 (1964)

13) A. J. Staverman, Rec. Trav. Chim. PoysBas, 60, 827 (1941), Verfkronik, 35, 284 (1962)

14) M. Farcasiu, Gordon Research Conference on Fuels Science, USA, June (1976)

15) J.M. Angelovich, G. R. Pastor, H. F. Silver, Ind. Eng. Chem. Process Des. Develop., 9, 106 (1970)

16) M. W. Kiebler, Ind. Eng. Chem., 32, 1389 (1940)

17) D. W. Van Krevelen, Fuel, 44, 229 (1965)

18）大沢, 石, 角田, 藤代, 工化, 73, 2212 (1970)

19) N. Y. Kirov, J.M. O'Shear, G. D. Seargent, Fuel, 46, 415 (1970)

20) 佐藤, 神谷, 燃協誌, 56, 598 (1977), 佐藤ら 第13回石炭科学会議 (1976), 同じく第 14 回石炭 科学会議 (1977)

21) 大内公耳ら，日化第36春季年会講演（1977）

22) Y.Sanada, H. Honda, Fuel, 45, 295 (1966)

23）園田，“炭素工業用粘結剤に関する研究” (1957)

24）古田，真田，投稿準備中 


\title{
Polymeric Character, Micell Structure and Compatibility of Coal
}

\author{
by Yuzo Sanada \\ (Hokkaido University)
}

SYNOPSIS:-Polymeric character and micell structure of coal are reviewed from view point of interaction between solvent and coal. Molecular weight per crossed unit of coal is of important factor determining not only chemical structure but physical properties of coal. The cohesive energy density i. e. solubility parameter of coal is estimated from solvent extraction or swelling equilibrium with solvent. It is stressed the fact that the physico chemical behaviours described above are correlated with compatibility between coal, coal blends and solvent. 


\section{****** 溶剂精製炭の化学構造に関する 最近の研究}

- 1977. 12. 1 受理一

東京大学* 神 谷佳男

\section{1. はしがき}

石炭を水素供与性芳香族系溶剤の存在下，400 450 ${ }^{\circ} \mathrm{C}$ で熱分解水素化抽出して得られる溶剤精製炭(SRC, Solvent Refined Coal) は，もとの石炭の種類に無関 係に注济同様な性質を示すといわれる。灰分を活とん ぞ含まず，硫黄招よび酸素含量も著しく低下してお り, 著しい改質効果をうけている。C 85〜88\%，融 点約 $200^{\circ} \mathrm{C}$, 発熱量約 $9,000 \mathrm{kcal} / \mathrm{kg}$, 分子量 $500 \sim$ 1,000 程度の化合物である。

SRC の生成に当たって消費される水素量は, 石炭 飞対し $2 \%$ 前後であるが，石炭に比してかなり石油 に近づいて特り，融点もあまり高くないために，石油 飞代る安価な液体燃料として，また触媒を使用しない プロセスとしての長所から，アメリカに抒いて重点的 に開発が押し進められている。

アメリカに扮いて SRC は燃料としての用途を目指 しているが，この改質炭は高炭化度瀝青炭の組成に近 く, 分子量 1,000 程度の炭素質物質であるために, 独 自の利用法が開発されてしかるべきであるう。わが国 の鉄鋼各社では，将来の原料炭事情を考慮して，一般 炭に粘結剤として配合し，高炉用コークスを製造する 方式に注目しているるようである。

SRC は性状が明らかにされるにつれて，利用法に 打ける多面的な発展も期待されるので, この方面の研 究を大いに振興すべきものと考光る。分析化学的な研 究は，アメリカに和いて急速に発展して捺り，石油系
重質油の化学構造研究の発展とあいまって, 多数の報 告が提出されている。

現時点に打いて，その概要を紹介することは，極め て意義深いものと考克，西兄て筆をとった次第であ る。

\section{SRC の生成と化学構造}

2.1 石炭の熱分解・水素化・抽出プロセス

石炭を -60 メッシュ程度に粉砕し, 部分的に水素 化された芳香族炭化水素（テトラリン，ヒドロフェナ ントレンなど)，あるいは水素により容易に水素化さ れる芳香族炭化水素（クレオソート油，アントラセン 油など）を主体とする溶剤中に懸濁し，加圧水素の存 在下で $400 \sim 450^{\circ} \mathrm{C}$ 程度に加熱すると, 石炭の大部 分が熱分解・水素化・抽出され，溶剤を留去すると $\mathrm{SRC}$ が得られる。連続運転を行なうと, 溶剤は石炭 から生成する軽質油によって次第に希橎されることに なる。

PAMCO 法 ${ }^{1225)}$ (図 1) では, 例光ば石炭/溶剤= $1 / 2$ の混合比で, 水素圧 $100 \mathrm{~kg} / \mathrm{cm}^{2}$, 予熱温度 $425^{\circ} \mathrm{C}$, 反応筒温度 $435^{\circ} \mathrm{C}$ (第 1 段), $400^{\circ} \mathrm{C}$ (第 2 段) で反応 を行ない，C 80\% 程度の石炭から約 60\% の収率で SRC を取得して扮り，石炭の反応率は $95 \%$ 程度で ある。

石炭液化反応に郝ける水素供与性溶剂の効果につい

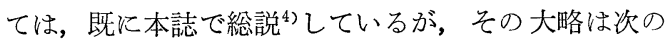
ようである。

循環溶剤

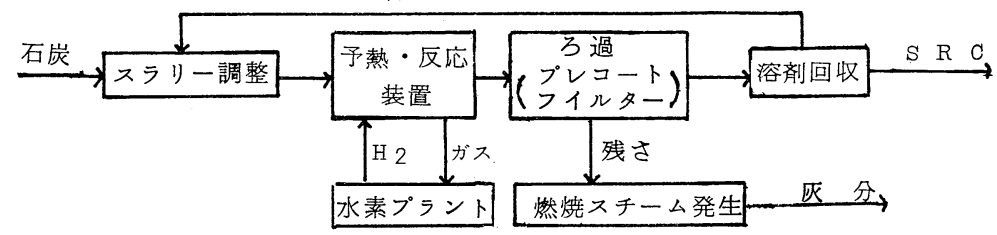

図 1 PAMCO 法の概 略 図

*工学部 東京都文京区本郷7-3-1 